Southern Illinois University Edwardsville SPARK

SIUE Faculty Research, Scholarship, and Creative Activity

$7-12-2013$

\title{
The impact of nitrogen contamination and river modification on a Mississippi River floodplain lake
}

Indu Karthic

Southern Illinois University Edwardsville, indu_karthic@yahoo.com

Richard B. Brugam Ph.D.

Southern Illinois University Edwardsville, rbrugam@siue.edu

William A. Retzlaff

Southern Illinois University Edwardsville, wretzla@siue.edu

Kevin Johnson

Southern Illinois University Edwardsville

Follow this and additional works at: http://spark.siue.edu/siue_fac

Part of the Biogeochemistry Commons, Environmental Indicators and Impact Assessment Commons, and the Water Resource Management Commons

\section{Recommended Citation}

Karthic, I., Brugam, RB., Retzlaff, WA., Johnson, K. 2013,The impact of nitrogen contamination and river modification on a Mississippi River floodplain lake, Science of the Total Environment 463-464: 734-742 http://dx.doi.org/10.1016/ j.scitotenv.2013.06.070

This Article is brought to you for free and open access by SPARK. It has been accepted for inclusion in SIUE Faculty Research, Scholarship, and Creative Activity by an authorized administrator of SPARK. For more information, please contact gpark@siue.edu. 


\section{Cover Page Footnote}

This article is the Accepted Manuscript version of a paper published by Elsevier in Science of the Total Environment, available online at http://dx.doi.org/10.1016/j.scitotenv.2013.06.070.

(C) 2013. This manuscript version is made available under the CC-BY-NC-ND 4.0 license http://creativecommons.org/licenses/by-nc-nd/4.0/ 


\title{
The impact of nitrogen contamination and river modification on a Mississippi River floodplain lake
}

\author{
Indu Karthic ${ }^{1}$ \\ Richard B. Brugam ${ }^{1,2}$ \\ William Retzlaff ${ }^{1}$ \\ and \\ Kevin Johnson ${ }^{1}$ \\ ${ }^{1}$ Southern Illinois University Edwardsville, Edwardsville, IL 62026 \\ ${ }^{2}$ Corresponding Author \\ (rbrugam@siue.edu)
}




\section{Abstract}

Anthropogenic nitrogen contamination has increased in ecosystems around the world (frequently termed the "nitrogen cascade"). Coke production for steel manufacturing is often overlooked as a source of nitrogen to natural ecosystems. We examined sediment cores from a Horseshoe Lake, a floodplain lake located just East of St. Louis Missouri (USA) to test whether a coking plant effluent could be traced using stable isotopes of nitrogen and diatom microfossils. The distribution of $\delta^{15} \mathrm{~N}$ values in surface sediment samples from the lake shows the highest values near the coking plant effluent. Analysis stable isotopes of nitrogen from sediment cores using a binary mixing model showed three sources of nitrogen since $1688 \mathrm{CE}$. The first source (active between 1688 and 1920 CE) had a calculated $\delta^{15} \mathrm{~N}$ value of $-.8 \pm .4 \%$. After 1920 a second source with a $\delta^{15} \mathrm{~N}$ of $20.2 \pm 2.0 \%$ became active. The diatom microfossil assemblages present from $1688 \mathrm{CE}$ to the late 1800 's are dominated by the planktonic species Aulacoseira granulata and periphytic and benthic genera Gomphonema, Cocconeis, and Lyrella. After the late 1800 's the diatom assemblages are dominated by Staurosira species indicating a shift of species from high flow riverine environments to epipelic species from a lake environment. Diatom microfossils did not respond to the changes in nitrogen sources, but seem to track the reduction in flooding due to leveeing of the floodplain and the isolation of the lake from the river. Our results show how stable isotopes of nitrogen can be used to track nitrogen inputs from industrial sources. They suggest that the high nitrogen input has not been a major source of eutrophication in the lake. The diatom results indicate that the increased nitrogen input was not a cause of eutrophication. 
Rather, diatom changes corresponded with changes in connectivity between the Mississippi River and its floodplain.

\section{Introduction}

The floodplains of large rivers in the temperate zone have been heavily modified by human activities (Junk et al. 1989; Sparks 1995; Sparks et al. 1998). In particular, dams modify natural flood regimes changing times of high water disrupting reproduction of river organisms. In addition levees (dikes) are constructed to prevent the natural inundation of large river floodplains protecting industrial and agricultural activities. Levees disrupt connectivity of the river with its floodplain endangering river biodiversity (Sparks 1995). These modifications allow the industrialization and urban development of floodplain land. In most industrialized countries floodplains have been developed for heavy industry because of proximity to inexpensive river transportation (Colten 1990).

The American Bottom is a floodplain on the eastern shore of the Mississippi River that has been isolated from the River by levees and has undergone intense industrialization including construction of oil refineries, stock yards, a steel plant and several lead smelters (Brugam et al. 2003; Brugam et al. 2012; Colten 1990).

\subsection{Using Stable Isotopes to Trace Nitrogen Inputs from a Steel Plant}

Anthropogenic increases in nitrogen levels have been recognized in many ecosystems worldwide. Galloway et al. (2003) called this process of contamination with fixed nitrogen the "nitrogen cascade". Long-distance transport of fixed nitrogen may cause 
changes even at remote sites (Wolfe et al. 2001). A major question is the impact of this increased nitrogen deposition on natural ecosystems.

The sedimentary record in lakes can provide a long-term view of the nitrogen cascade because paleolimnologists have discovered that the isotopic composition of nitrogen in lake sediment can be used to reconstruct sources of anthropogenic nitrogen to lake biota. Many investigations have shown that wastewater contamination of natural waters results in elevated $\delta^{15} \mathrm{~N}$ values of plankton and sediment (Fenech et al. 2012; Schindler et al. 2008). Erlenkeuser et al. (1974) linked increased $\delta^{15} \mathrm{~N}$ in sediment cores from the Baltic Sea with anthropogenic nitrogen sources. Similarly, Köster et al. (2005) found a rise in $\delta^{15} \mathrm{~N}$ values in a sediment core from Walden Pond, Massachusetts. This change occurred at the same time that the diatoms of the lake shifted to more eutrophic forms. The investigators suggest that there has been wastewater seepage into the lake. Leavitt et al. (2006) traced the effluent of the Regina, Saskatchewan, wastewater treatment plant through the lakes of the Qu'Appelle River using stable isotopes of nitrogen.

In contrast with wastewater contaminated lakes $\delta^{15} \mathrm{~N}$ values declined in the sediment of high altitude lakes in the Rocky Mountains near Denver (Baron et al. 2000, Wolfe et al. 2001). Vreca and Muri (2006) found similar declines in $\delta^{15} \mathrm{~N}$ in Slovenian mountain lakes. A potential source of low $\delta^{15} \mathrm{~N}$ nitrogen to these lakes is long-distance transport of nitrogen oxides from urban air pollution. Holtgrieve et al. (2011) showed that these declines in $\delta^{15} \mathrm{~N}$ are widespread in Northern Hemisphere wilderness lakes supporting Galloway et al.’s “nitrogen cascade” hypothesis that even distant human activities are increasing nitrogen inputs to ecosystems (Galloway et al. 2003). 
The steel industry is another potential, but frequently overlooked, source of anthropogenic nitrogen to natural ecosystems. Coke ovens produce an important fuel for steel making and smelting of non-ferrous metals (Cairns 1965). The ovens produce large amounts of ammonia gas as a byproduct. This gas is derived from nitrogen compounds in the coal used to produce coke. Usually, to prevent air pollution, this effluent gas is dissolved in a water wash as ammonium ion, and released into local water bodies. Before release, the effluent may be biologically treated to allow nitrification to convert the ammonium to nitrate (Cairns 1965; Melcer et al. 1984; Zhang et al. 2009). This nitrate will provide a large nitrogen source for receiving lakes and streams that may carry an isotopic signature that reflects any fractionation occurring in the coke production process. Our hypothesis is that nitrogen from steel making represents an important additional nitrogen source to natural ecosystems that will be traceable in the sedimentary record using stable isotopes and that this nitrogen source can potentially cause eutrophication in a receiving lake. A two-source mixing model proposed by Fry (2006) can be used to determine the isotopic composition of anthropogenic nitrogen sources. Diatom microfossils from the lake sediment can be used to trace eutrophication (Wolfe et al. 2001). We used Horseshoe Lake, a Mississippi River floodplain lake located east of St. Louis Missouri, USA to examine the impact of excess nitrogen additions to a floodplain lake.

\subsection{Horseshoe Lake and Human Modifications to the Mississippi River Floodplain}

Horseshoe Lake is a 860 ha (2150 acres, Hill et al. 1981), 2 m deep oxbow lake. The lake is located adjacent to Granite City which was incorporated in 1896 shortly after Niedringhaus Steel Company (now the Granite City Works of US Steel Company) was 
built on the lakeshore. The lake is owned and managed by the Illinois Department of Natural Resources for fishing and water fowl hunting. For purposes of this study, we have divided the lake into 5 basins - the Southwest Basin, the Main Basin, the Middle Basing, the Southeast Basin and Canteen Lake (Fig. 1). The Southeast Basin is drained during July and August to produce a wetland to support water fowl. The lake has three major inflows. Nameoki Ditch (Fig. 1) is a storm-water inflow that drains urban areas in Granite City. Elm Slough is a wetland that drains agricultural land. The Granite City Works has an effluent that includes nitrate from the coking process (Cairns 1966). The company now produces 650,000 tons of coke a year from 120 ovens. Cairns (1966) summarizes water pollution control at the company in the mid 1960's. In 1966 the facility was using 246,000 cu m of water per day pumped from the Mississippi River. This water was recycled several times and discharged into Horseshoe Lake after treatment (Cairns 1966). The wastewater treatment plant for the steel company is separate from the Granite City municipal sewer system so it treats very little domestic sewage. Wastewater for Granite City is treated and released into the Mississippi River (Cairns 1966).

Horseshoe Lake is located in the American Bottom, the largest floodplain on the Mississippi River north of New Orleans. Because of frequent flooding, the floodplain has been subject to extensive anthropogenic modification since the arrival of EuroAmericans. Before colonization, the floodplain was a complex network of waterways that frequently flooded. In modern times only a remnant of the pre-settlement wetland exists and the floodplain has been protected by an extensive series of levees (Skele 1988). Flood control was accomplished slowly starting as early as 1819 when the Illinois state 
legislature approved funding to drain lakes in the American Bottom. The American Bottom was completely inundated both in 1844 and $1903 . \quad$ In 1908 the East Side Levee and Sanitary District was set up to provide funding to improve levees (Colten 1990).

The historical record of leveeing in the American Bottoms is representative of many of the large rivers of the world. The result has been a disruption of river and floodplain ecosystems and threats to the diversity of river organisms (Junk et al. 1989). The sedimentary record of lakes may record the changes of floodplain and river ecosystems in response to development of the river for transportation and flood protection.

\section{Methods}

\subsection{Lake Sediment Sampling and Preparation}

Eighty-two surface sediment samples were taken from Horseshoe Lake using an Ekman dredge. Sampling sites were arranged at approximately $160 \mathrm{~m}$ intervals along a transect beginning in the Southwest basin of the lake. These samples were used to construct the contour map in Figure 1. Distances and locations of sampling points were measured using a Garmin GPS V geographic positioning system. Each dredge haul was subsampled using a small scoop to remove a layer of the surface sediment. This sample was placed in a Whirl-Pak bag until further processed.

Sediment cores were taken manually in the summer of 2005 in the Southwest Basin, the Main Basin and the Canteen Lake Basin of Horseshoe Lake using a Plexiglas tube attached to steel rods (Fig. 1). Seventeen cores (numbered H1 to H17) were taken from the lake. Two cores were selected from the Main Basin (H3, H5) and one (H8) 
from the Southwest Basin (Fig. 1) for nitrogen isotope analysis. All core sites were located in water between 1 and $2 \mathrm{~m}$ deep.

Cores were returned to the laboratory in vertical condition and were extruded vertically. Each core was sliced at $1 \mathrm{~cm}$ intervals and the slices were stored in Whirl-Pak bags until subsampled.

\subsection{Stable Isotope Methods}

Sediment samples for stable isotope analysis were dried at $60^{\circ} \mathrm{C}$ and ground in a Spex cryogenic grinder. The method of Kendall (1998) for plankton was used to remove inorganic carbon. Each sample was moistened with distilled water and placed in dessicator for 24 hours. The desiccator contained no drying agent, but did contain a 250 $\mathrm{ml}$ beaker filled with concentrated $\mathrm{HCl}$. The $\mathrm{HCl}$ gas produced by the acid removed any $\mathrm{CaCO}_{3}$ from the sediment. After exposure to the $\mathrm{HCl}$ gas produced by the acid, the samples were re-dried. Samples were sent to the Cornell University Isotope Lab for analysis.

\subsection{Diatom Preparation}

Diatom microfossils were prepared from core H8 using a method similar to Moos et al. (2005). Approximately $0.5 \mathrm{gm}$ of sediment was placed in a plastic digestion vessel (Environmental Express No.SC415). The organic matter in the sample was removed from the sediment using a solution of $50 \% \mathrm{HNO}_{3}$ and $50 \% \mathrm{H}_{2} \mathrm{SO}_{4}$. The solution was heated to $90^{\circ} \mathrm{C}$ for 4 hours using an Environment Express hot block. The samples were removed from the hotblock and allowed to cool and settle for 24 hours. The acid was aspirated off and replaced with de-ionized water. This process was repeated every 24 hours until the remaining acid was removed. Subsamples of the diatom suspension were dried on 
coverslips and mounted in Naphrax mounting medium, diatoms were identified using a 100x oil immersion lens. Because of the low concentration of diatoms in the lake sediment a minimum of 150 individuals were counted at each core depth.

\subsection{Dating}

Dating of the cores from Horseshoe Lake was accomplished using a combination of

${ }^{210} \mathrm{~Pb}$, radiocarbon and known changes in fossil pollen. Cores $\mathrm{H} 3$ and $\mathrm{H} 8$ were dated at the St. Croix Watershed Research Center, Marine on St. Croix, using alpha counting of ${ }^{210} \mathrm{Po}$, a daughter of ${ }^{210} \mathrm{~Pb}$ plated on $\mathrm{Ag}$ discs. Core $\mathrm{H} 5$ was dated at Southern Illinois University Edwardsville using ${ }^{210} \mathrm{Bi}$ ingrowth. (Kharkar et al. 1976).

In all cores supported ${ }^{210} \mathrm{~Pb}$ was determined by averaging deep core samples. This value was subtracted from the total ${ }^{210} \mathrm{~Pb}$ activity in the sediment to determine atmospherically-derived ${ }^{210} \mathrm{~Pb}$ (termed “unsupported ${ }^{210} \mathrm{~Pb}$ ”). Dates were calculated using the CRS method (Vermillion et al. 2005; Appleby and Oldfield 1978).

The increase in pollen from a North American agricultural weed, Ambrosia, was used as an indicator of the arrival of Euro-American farmers in the land area surrounding the lake in 1808 (Fig. 2). This date was determined from historic records (W.R. Brink Co. 1882). Pollen diagrams for cores $\mathrm{H} 3$ and $\mathrm{H} 5$ are presented in Brugam et al. (2003).

Two conventional radiocarbon dates were taken from core H5. One date was taken between 50 and $56 \mathrm{~cm}$ - the same depth as the increase in Ambrosia pollen. This date was used to make a reservoir correction. The actual date of the Ambrosia increase (1808 CE, $142 \mathrm{BP})$ was subtracted from the radiocarbon date $\left(660 \pm 80{ }^{14} \mathrm{C}\right.$ years $\left.\mathrm{BP}\right)$ resulting in a value to correct for reservoir effects. The second date was taken between 63 and $73 \mathrm{~cm}$. The resulting date was $710 \pm 80{ }^{14} \mathrm{C}$ years BP. Correcting for reservoir 
effects, the date is $1758 \mathrm{CE}$. Cores $\mathrm{H} 5$ and $\mathrm{H} 8$ had no radiocarbon dates so ages older than 120 years (the limit for ${ }^{210} \mathrm{~Pb}$ dating) have been extrapolated from the deepest valid ${ }^{210} \mathrm{~Pb}$ dates.

\subsection{Modern Phytoplankton and Zooplankton Sampling}

Phytoplankton and zooplankton samples were taken in the Southwest and the Main Basins at varying time intervals from November 2010 to October 2011 to compare with sediment isotopic values. Phytoplankton was sampled using a glass bottle. Zooplankton was sampled using an $80-\mu$ mesh nitex zooplankton net. Within 2 hours both zooplankton and phytoplankton samples were filtered using a GFC glass fiber filter.

Phytoplankton and zooplankton filters were dried at $60^{\circ} \mathrm{C}$ for 24 hours. Dried samples were pulverized with a SPEX cryogenic grinder. Inorganic carbon was removed from the samples using the same methods listed above for sediment samples. Samples with inorganic carbon removed were sent to the Cornell Isotope Laboratory at Cornell University, Ithaca, N.Y. for analysis.

\section{Theory and Calculations}

Fry (2006) proposed that a simple mixing model can be used to estimate the isotopic ratios of nitrogen sources to sediment cores. Fry's (2006) analysis was an extension of the general two source mixing model for isotopes presented by Faure and Mensing (2005) modified for stable isotopes of nitrogen and carbon. A similar approach has been used by Brugam et al. (2012) using Pb isotopes at Horseshoe Lake.

When two sources of differing isotopic composition are mixed, the resulting mixture represents an average of the two sources weighted for the amount of nitrogen 
contributed by each source. The basic equation for this mixing model is (notation follows Fry 2006):

$$
\delta_{\text {sample }} *\left(\mathrm{~m}_{1}+\mathrm{m}_{2}\right)=\delta_{\text {source } 1} * \mathrm{~m}_{1}+\delta_{\text {source } 2} * \mathrm{~m}_{2}
$$

Where: $\quad \delta_{\text {sample }}=$ the isotopic ratio of the final mixture (sample)

$$
\begin{aligned}
& \delta_{\text {sourcel }}=\text { the isotopic ratio of source } 1 \\
& \delta_{\text {source } 2}=\text { the isotopic ratio of source } 2 \\
& \mathrm{~m}_{1}=\text { the } \% \mathrm{~N} \text { from source } 1 \text { mixed into the sample } \\
& \mathrm{m}_{2}=\text { the } \% \mathrm{~N} \text { from source } 2 \text { mixed into the sample }
\end{aligned}
$$

Equation 1 can be rearranged to show the isotopic composition of the sample:

$$
\delta_{\text {sample }}=\left(\delta_{\text {source } 1} * \mathrm{~m}_{1}+\delta_{\text {source } 2} * \mathrm{~m}_{2}\right) /\left(\mathrm{m}_{1}+\mathrm{m}_{2}\right)
$$

As is, this equation has too many variables to conveniently solve. However, because of conservation of mass, the total mass of nitrogen in the sample must equal the sum of the masses of contributed by the two sources (Equation 3).

$$
\mathrm{m}_{\mathrm{t}}=\mathrm{m}_{1}+\mathrm{m}_{2} \quad \text { Where } \mathrm{m}_{\mathrm{t}}=\text { the total mass of the sample }
$$

Equation 2 can be substituted into equation 3 to reduce the number of unknowns.

$$
\delta_{\text {sample }}=\left[\delta_{\text {source } 1} * \mathrm{~m}_{1}+\delta_{\text {source } 2} *\left(m_{t}-m_{1}\right)\right] / m_{t}
$$

Fry (2006) suggests that the mixing model might be taken further to determine the background (source 1) and pollution (source 2) nitrogen sources mathematically. Equation 4 describes a rectangular hyperbola. The asymptotes of the hyperbola are $\delta_{\text {source } 1}$ and $\delta_{\text {source2. }}$. These asymptotes can be found by graphing $\delta_{\text {sample }}$ against $1 / \% \mathrm{~N}$ forming a "reciprocal plot". In our case, when the sediment $\delta^{15} \mathrm{~N}$ is plotted against the reciprocal of the sediment $\% \mathrm{~N}$, the $\mathrm{y}$-intercept of the line will be the isotopic ratio of the pollution source. Turner et al. (2006) used this method to calculate carbon sources to the sediment 
of the Charlotte Harbor estuary in Florida. We can also use it to determine nitrogen sources to sediment organic matter in Horseshoe Lake.

Application of reciprocal plots to determine $\mathrm{N}$ sources to a lake sediment can be complicated if there are three or more $\mathrm{N}$ sources (Faure and Mensing 2005). However, in a sediment core, multiple sources may be dominant at different times during the history of the lake. The result will be that the two-component mixing model proposed here will apply only to certain segments of core. The result of a reciprocal plot will be a series of independent line segments with different y-intercepts representing different sources. Three sources will result in a "ternary" mixing diagram where the mixing curves form a triangle with each vertex indicating the isotopic composition of an isotope source (Faure and Mensing 2005).

\section{Results}

\subsection{Surface sediments and plankton}

Surface sediment samples can indicate the spatial distribution of effluents with anomalous $\delta^{15} \mathrm{~N}$ values within a lake. The $\delta^{15} \mathrm{~N}$ values of surface sediment from Horseshoe Lake show distinct differences among basins (Fig 1). There is a gradient of $\delta^{15} \mathrm{~N}$ values from the Southwest Basin to the Southeast Basin. The Southwest Basin has the highest values, averaging 12.2 $\pm 2 \%$ (Fig 2). The Main and Middle Basins have intermediate values $(9.4 \pm 0.5 \%$ and $9.1 \pm 0.8 \%$ respectively) The Southeast Basin had the lowest values averaging $6.6 \pm 0.5 \%$. A Kruskal-Wallis non-parametric one-way analysis of variance test among the basins was highly significant $(\mathrm{p}<.001)$.

Modern phytoplankton and zooplankton samples taken from the Southwest Basin and the Main Basin have higher $\delta^{15} \mathrm{~N}$ values than their respective surface sediments (Fig. 
2). However, the $\delta^{15} \mathrm{~N}$ values for the plankton from the Southwest Basin and the Main Basin were not significantly different by a t test.

\subsection{Stable Isotopes in Sediment cores}

Sediment age vs. depth curves were established for the Horseshoe Lake cores using ${ }^{210} \mathrm{~Pb}$ analysis, radiocarbon dating and pollen analysis. Extrapolation of ${ }^{210} \mathrm{~Pb}$ dates indicates that core $\mathrm{H} 8$ reached the oldest sediment (1688 CE).

The percent $\mathrm{N}$ and $\delta^{15} \mathrm{~N}$ profiles for all three cores were similar (Fig 4). Sediment percent $\mathrm{N}$ was highest before 1900 (0.6 to $0.9 \%)$, declining to a lower value $(0.3 \%)$ around 1900. Because core H8 penetrates more deeply into the sediment and earlier in time it shows that the high pre-1900 values are really a peak percentage $(0.9 \%)$ that is reached in 1833. Core $\mathrm{H} 8$ has low N percentages before the 1760's $(0.30 \%)$

Values of $\delta^{15} \mathrm{~N}$ rise after 1900 (Fig. 4). In all cores the maximum values are reached in the 1920's and continue to the sediment surface. Consistent with the differences $\delta^{15} \mathrm{~N}$ values in surface samples, the maximum $\delta^{15} \mathrm{~N}$ values vary with core location. The core from the Southwest Basin (core H8) reaches the highest $\delta^{15} \mathrm{~N}$ value (15.19\%o). Cores H5 and H3 from the Main Basin reach lower maximum values (9.76 \%o and $12.01 \%$ ) than core $\mathrm{H} 8$ (Fig 4).

Percent organic carbon values in core 8 reaches a maximum of $10.9 \%$ in the mid1800's (Fig. 4). Cores H3 and H5 show little change in percent organic carbon over time. In all three cores $\delta^{13} \mathrm{C}$ declines from $-24 \%$ to $-26 \%$ after 1900 . Carbon to nitrogen ratios do not vary much from $10(\mathrm{C}: \mathrm{N})$ throughout all depths in all cores (Fig. 4).

Using the mixing model approach of Fry (2006) we estimated the isotopic

composition of the multiple sources of nitrogen to Horseshoe Lake (Fig. 5). When $\delta^{15} \mathrm{~N}$ 
values for each sediment sample are plotted against the reciprocal of $\% \mathrm{~N}$ the $\mathrm{y}$-intercept of the regression line is the isotopic composition of one of the ${ }^{15} \mathrm{~N}$ sources. Two groups of data lying along two different regression lines are revealed when the ${ }^{15} \mathrm{~N}$ values of Horseshoe Lake core samples are plotted against 1/\%N (Fig. 5). Samples from core levels deposited after approximately 1920 lie along a line of negative slope with a y-

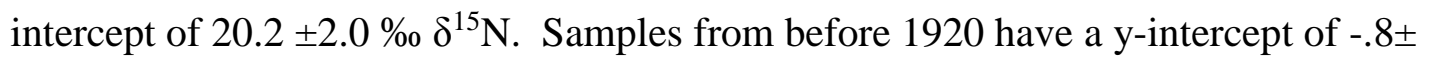
$.4 \%$. This value is not significantly different from 0 . The regression lines for both sets of data cross at a $\delta^{15} \mathrm{~N}$ value of $5.3 \%$. These results suggest that there have been at least 3 different sources of nitrogen active at different times in the history of the lake. Before 1920 the sources of $\mathrm{N}$ to the lake sediment were a low $\delta^{15} \mathrm{~N}$ source $(-.8 \%$ mixed with an intermediate $\delta^{15} \mathrm{~N}$ source $\left(5.34 \%\right.$ ). After 1920 , the low $\delta^{15} \mathrm{~N}$ source was replaced by a very high $\delta^{15} \mathrm{~N}$ source $\left(20.8 \%\right.$ ). This higher $\delta^{15} \mathrm{~N}$ source mixed with the 5.3\% source.

Figure 5 indicates that the low $\delta^{15} \mathrm{~N}$ source disappeared after 1920 because there are no data points indicating the presences of such mixtures. If mixing between the high $\delta^{15} \mathrm{~N}$ source and the low $\delta^{15} \mathrm{~N}$ source did exist, they would plot on a mixing line between the two regression lines on the diagram. There is no evidence of a mixing line between the low and high $\delta^{15} \mathrm{~N}$ sources.

\subsection{Diatom Microfossils in Core $\mathrm{H8}$}

Sediment diatom microfossils from core $\mathrm{H} 8$ fall into two contrasting assemblages. Before about $1900 \mathrm{CE}$, the assemblages are characterized by many epiphytic genera including Gomphonema, Cocconeis and the species Aulacoseira granulata and A. ambigua. This community includes Lyrella cf. hennedyi. After the late 1800's and early 1900's, diatom assemblages shift to dominance by Staurosira construens var. 
venter, S. construens and Pseudostaurosira brevistriata. Craticula cuspidata, Neidium iridis and Amphora ovalis are present throughout the core (Fig. 6).

\section{Discussion}

\subsection{Sediment Isotopes}

Surface sample analysis shows that the likely source of the high $\delta^{15} \mathrm{~N}$ fixed nitrogen is the Southwest Basin of the lake which is also the location of the steel plant effluent (Fig. 1). The surface sample analysis is consistent with the hypothesis that the steel plant effluent is the source of the high $\delta^{15} \mathrm{~N}$ effluent. In addition the time course of the increase in sediment $\delta^{15} \mathrm{~N}$ from the cores matches the chronology of the coking plant - the likely source of highly fractionated fixed nitrogen. There is no similar elevated isotopic value in sediment near Nameoki Ditch or Elm Slough (Fig. 1). Many other investigators have shown that the spatial distribution of sediment $\delta^{15} \mathrm{~N}$ tracks pollution sources (Leavitt et al. 2006). Similarly, our work at Horseshoe Lake suggests that a high $\delta^{15} \mathrm{~N}$ source enters the Southwest Basin of the lake. However, modern plankton samples from the Southwest Basin do not show significantly higher $\delta^{15} \mathrm{~N}$ values than the lake's Main Basin.

The Southeast Basin has the lowest $\delta^{15} \mathrm{~N}$ of the study (Figs. 1 and 2) suggesting that the 2 month period in summer when the basin is drained has a strong impact on nitrogen cycling. It is unclear why there is such a strong and statistically significant difference in the $\delta^{15} \mathrm{~N}$ values of the sediment organic matter.

The $\delta^{13} \mathrm{C}$ values decline in all sediment cores after 1900 suggesting eutrophication of the lake. Torres et al. (2012) found a similar decline over time in Lake Okeechobee, a large eutrophic Florida Lake. They suggest that the decline occurs because of increasing 
carbon limitation of photosynthesis as a lake becomes more eutrophic. Our data corroborate this hypothesis.

$\mathrm{C} / \mathrm{N}$ ratios in all cores are nearly constant through time with values near 10 . The relatively low values at Horseshoe Lake suggest that most of the organic matter in the sediment comes from phytoplankton. Sediment organic matter derived from phytoplankton has relatively low $\mathrm{C} / \mathrm{N}$ ratios $(<10)$ whereas sediment carbon derived from terrestrial plants has higher C/N ratios (>20) (Kraushal and Binford 1999).

\subsection{Mixing Model Analysis}

Mixing model analysis can also be used to test the hypothesis that the sources of fixed nitrogen to the lake changed after the construction of the coking plant. This analysis shows that before 1920 the major source of nitrogen to the lake had an isotopic composition near $0 \%$ indicating that biological nitrogen fixation was the major source of nitrogen to the lake (Kendall 1989) . $\mathrm{N}_{2}$ fixation by cyanobacteria does not fractionate nitrogen (Kendall 1998). This source indicates that biological nitrogen fixation by cyanobacteria was a major source of nitrogen to the lake until about 1920.

After 1920, the nitrogen biogeochemistry of the lake changes significantly. After this date biological nitrogen fixation was replaced by a new high $\delta^{15} \mathrm{~N}$ source. The disappearance of the cyanobacterial source is consistent with the addition of a new, large nitrogen source to the lake. Such an increase in nitrogen loading would remove the competitive advantage of nitrogen fixing cyanobacteria have when nitrogen is limiting (Schindler et al. 2008). Hill et al. (1981) surveyed the phytoplankton of the Horseshoe Lake and found cyanobacteria to dominate. We propose that before 1920 cyanobacteria had a much more important role in the nitrogen cycle of the lake than they do now. 
We also propose that the high $\delta^{15} \mathrm{~N}$ source that appeared in the lake is the coke plant effluent from the Granite City Works. The process of flue gas washing should fractionate the nitrogen isotopes of nitrogen because ammonia volatilization favors the lighter isotope leaving the heavier isotope to be preferentially dissolved in the wash water. Volatilization of ammonia in biological systems increases the $\delta^{15} \mathrm{~N}$ values of the residual ammonia because of this fractionation process (Mizutani et al. 1986). The addition of this new nitrogen source to the lake when the coke plant was opened in 1921 changed the biogeochemistry of nitrogen in the lake, reducing biological nitrogen fixation.

Unfortunately, there are other nitrogen sources to the lake that cannot be ruled out. The USEPA (1975) concluded that $27 \%$ of the nitrogen loading to the lake came from Nameoki Ditch and 34\% came from other sources including the steel plant effluent. High $\delta^{15} \mathrm{~N}$ is characteristic of domestic wastewater contamination (Leavitt et al. 2006). Although Granite City domestic wastewater is treated and discharged directly into the Mississippi River, the Nameoki Ditch could also be supplying nitrogen contaminated runoff to the lake.

\subsection{Diatoms}

The diatom assemblages from core $\mathrm{H} 8$ are not consistent with a eutrophication model resulting from the shift in nitrogen source. In the Norfolk Broads (a group of shallow lakes in the UK) Bennion et al. (2001) found a shift in diatom assemblages from a Staurosira-dominated community to a plankton-dominated one. They interpreted this change as an increase in trophic status with an epipelic community representing clear water being replaced by a plankton community. This shift could represent eutrophication 
as described for shallow lakes by Scheffer and van Nes (2007). However, Bennion et al. (2001) note the difficulties of trophic status reconstruction when Staurosira is common because of its broad nutrient tolerances.

The diatom assemblages at Horseshoe Lake are problematical because they seem to represent a shift from a plankton-dominated community with Aulacoseira granulata to a Staurosira-dominated assemblage. Aulacoseira granulata, although a planktonic species, was found mostly in shallow, alkaline lakes in a survey of Minnesota diatom microfossils (Brugam 1983,1993). The shift from a planktonic community to an epipelic community is exactly the opposite change that occurred in the Norfolk Broads. It is difficult to interpret this change as a eutrophication response at Horseshoe Lake.

It may be that the change in diatom assemblages in Horseshoe Lake during the late 1800 's does not represent eutrophication at all, but may represent the more profound change in American Bottoms ecology that was caused by the increasingly effective flood control measures that removed connections between the floodplain and the River. A particularly problematical species found in Horseshoe Lake is Lyrella hennedyi (Wm.Smith) Stickle et Mann. Round et al. (1990) note that the species is a heavily silicified diatom that is found in fossil assemblages with evidence of dissolution. This description certainly fits the Horseshoe Lake diatom assemblages. The genus Lyrella has also been found in marine beach sands around the world (Mann 1997; Mann and Stickle 1993). We suggest that the loss of the genus Lyrella from the lake at this time is indicative of the change in the floodplain. This genus is present in sandy habitats (Mann 1997; Mann and Stickle 1993) which might be expected in a regularly flooded backwater environment where high flow regimes were probably common. Various Lyrella species 
have been found in rivers and estuaries around the world (Amal 2012; Majewska et al. 2012, Moura et al. 2007). We hypothesize that the prevention of flooding has modified lake habitats by removing periods of high flow thus expanding fine sediment habitats for epipelic species like Staurosira construens var. venter and shrinking coarse, sandy habitats favored by Lyrella.

\section{Eutrophication of the Lake}

Modern Horseshoe Lake is highly eutrophic with a mean total phosphorus concentration of $275 \mu \mathrm{g} / \mathrm{L}$ (Hill et al. 1981). The lowest total phosphorus concentrations in the 1975 US EPA survey were found adjacent to the steel plant effluent. In 1975 the USEPA concluded that the lake was phosphorus-limited (USEPA 1975). The role of the Granite City Steel effluent in maintaining the high trophic status of the lake is an important practical question. A domestic wastewater treatment facility effluent has high concentrations of both nitrate and phosphate. However, the steel plant industrial effluent contains very little phosphate but large amounts of nitrate (Luthy 1981). The question is to what extent does the coke plant effluent contributes to the eutrophication of the lake? The diatom assemblages from Horseshoe Lake do not seem to indicate eutrophication as a result of human activities. They seem to be responding to shifts in habitat suitability due to changes in flood regimes. The mixing model analysis suggests that the contribution of biological nitrogen fixation by cyanobacteria was much larger in presettlement times than it is now suggesting that the new nitrogen effluent had little impact on lake trophic status and may actually have reduced cyanobacterial blooms.

The lack of impact from the nitrate effluent at Horseshoe Lake is consistent with

limnological theory. Most limnologists agree that phosphate is the key nutrient inducing 
eutrophication in lakes. In particular Schindler et al. (2008) present experimental evidence that nitrate inputs cannot control eutrophication and that phosphate is the key limiting nutrient for primary production in most lakes. In their classic experiment, Schindler et al. (1977) added nitrate, bicarbonate and phosphate to one basin of a lake that had been partitioned into two sections. The second section received only nitrate and bicarbonate. Only the basin receiving the phosphate became eutrophic suggesting that phosphate alone is the limiting factor for eutrophication. Schindler et al. (2008) continued the experiment for 37 years without any evidence that nitrate supports eutrophication. Schindler et al. (2008) clearly state "Eutrophication of lakes cannot be controlled by reducing nitrogen input". Carpenter (2008) argues that control of phosphate - not nitrate -- effluents is critical to mitigating eutrophication.

The nitrogen effluent from the coking plant certainly did modify nitrogen cycling in the lake. It may have reduced biological nitrogen fixation in the lake. Unlike the oligotrophic nitrogen-limited high mountain lakes which show eutrophication from air pollution-derived nitrates (Holtgrieve et al. 2011; Vreca and Muri 2006; Wolfe et al. 2001), Horseshoe Lake probably was and continues to be phosphorus-limited with plenty of fixed nitrogen to support primary production. Thus, a nitrogen effluent is unlikely to cause further eutrophication.

Ultra-oligotrophic, high altitude lakes may be especially susceptible to eutrophication by nitrogen addition. Wolfe et al. (2001) showed changes in diatoms consistent with eutrophication in high altitude lakes with enhanced fixed nitrogen inputs from atmospheric deposition. These lakes may be susceptible to eutrophication by nitrogen addition because general nutrient loading rates are so low. These lakes are 
unlike Horseshoe Lake which is a lowland lake that should have sufficient natural inputs of nutrients to be moderately eutrophic.

The experiments of Schindler et al. $(1977,2008)$ support the hypothesis that the steel plant effluent at Horseshoe Lake may not be the cause of eutrophication even though it is the source for a large fraction of the nitrogen in the sediment of the lake. The effluent is also likely to be the major source of nitrogen for much of the lake biota. However, the amount of primary production in the lake is not limited by nitrogen inputs, but by phosphate inputs. The coking plant effluent is unlikely to contain large amounts of phosphate. However, Nameoki Ditch and Elm Slough are potential alternative sources of the phosphate that controls the trophic status of the Lake.

\section{Conclusions}

Stable isotopes can be used to track nitrogen from coke plant effluent in a lake. An analysis of sediment cores from a Horseshoe Lake, a lake receiving treated coke plant effluent, shows that there was a major change in nitrogen biogeochemistry when the plant began operation. At that time lake sediment organic matter shifted from receiving most of its nitrogen from biological nitrogen fixation to receiving a significant fraction of nitrogen from a high $\delta^{15} \mathrm{~N}$ source. This source is likely the coke plant effluent. The spatial distribution of surface sample $\delta^{15} \mathrm{~N}$ values also suggests that nitrogen from the coke plant is this source. Diatom microfossils do not indicate that the increased nitrate loading caused further eutrophication in excess of what had already been caused by urban development around the lake. Fossil diatom assemblages appear to be more sensitive to changes in the flooding regime caused by flood control structures (levees) that prevent rapid flow of Mississippi River water through the lake. 


\section{Acknowledgements}

We thank the Illinois Groundwater Consortium for funding this project. We thank the SIUE Graduate School for the Research Grant for Graduate Students funding to I. Karthic for this study. We also thank Dr. Daniel Engstrom of the St. Croix Watershed Research Center, Marine on St. Croix, Minnesota, for dating the Horseshoe Lake cores.

\section{Literature Cited}

Amal, ME. The use of diatom indices for the assessment of Shatt AL-Arab river water quality. Journal of Basrah Researches (Sciences) 2012;38: 114-24

Appleby PG, and Oldfield F. The calculation of lead-210 dates assuming a constant rate of supply of unsupported ${ }^{210} \mathrm{~Pb}$ to the sediment. CATENA $1978 ; 5: 1-8$

Baron JS, Rueth HM, Wolfe AM, Nydick KR, Allstott EJ, Minear T et al. Ecosystem Responses to Nitrogen Deposition in the Colorado Front Range. Ecosystems 2000;4: 352 $-68$

Bennion H, Appleby PG, Phillips GL. Reconstructing nutrient histories in the Norfolk Broads, UK: Implications for the role of diatom total phosphorus transfer functions in shallow lake management J. Paleolimnol. 2001; 26:181-204.

Brink, WR Co History of Madison County, Illinois with Illustrations Edwardsville, IL : W R Brink \& Co; 1882

Brugam, RB. The relationship between fossil diatom assemblages and limnological conditions. Hydrobiologia 1983;98:223-35.

Brugam, RB.. Surface sample analogues of Elk Lake fossil diatom assemblages. Geol Soc Am Spec Pap1993;276: 189-214.

Brugam RB, Bala I, Martin J, Vermillion B, and Retzlaff WA The Sedimentary Record of Environmental Contamination in Horseshoe Lake, Madison County, Illinois Trans Ill State Acad Sci 2003;96:205-18

Brugam, RB, Ketterer M, Maines L, Lin ZQ, and Retzlaff WA Application of a simple binary mixing model to the reconstruction of lead pollution sources in two Mississippi River floodplain lakes. J. Paleolimnol. 2012;47:101-12.

Cairns DF Stabilization lagoons successfully treat steel mill wastes. Journal Water Pollution Control Federation 1966;38:1645-1655 
Carpenter SR. Phosphorus control is critical to mitigating eutrophication. Proc Natl Acad Sci U S A 2008;105:11039-11040

Colten, CE. Environmental development in the East St. Louis Region, 1890-1970. Environmental History Review 1990;14:93-116.

Erlenkeuser H, Suess E, Willkomm H Industrialization affects heavy metal and carbon isotope concentrations in recent Baltic Sea sediments. Geochim et Cosmochim Acta $1974 ; 38: 823-42$

Faure G, and Mensing TM Isotopes: Principles and Applications Third Edition Hoboken, NJ John Wiley and Sons, Inc. 2005.

Fenech C, Rock L, Nolan K, Tobin J, Morrissey, A. The potential for a suite of isotope and chemical markers to differentiate sources of nitrate contamination: A review. Water Res 2012;46: 2023-2041.

Fry, B Stable Isotope Ecology Springer Science - Business Media, LLC 2006.

Galloway JN, Aber, JD, Erisman, JW, Seitzinger SP, Howarth, RW, Cowling EB et al. The nitrogen cascade. Bioscience 2003. 53: 341 - 356.

Hill TE, Evans RL, and Bell JS. Water Quality Assessment of Horseshoe Lake, SWS Contract Report 249, Illinois Institute of Natural Resources, Springfield 1981.

Holtgrieve GW, Schindler, DE, Hobbs WO, Leavitt PR, Ward, EJ, Bunting L, et al. A coherent signature of anthropogenic nitrogen deposition to remote watersheds of the Northern Hemisphere Science 2011;334:1545-1548.

Junk, W, Bayley PB, and Sparks RE. The flood pulse concept in river-floodplain systems. Can J Fish Aquat Sci Spec. Pub. 1989;106:110-27

Kendall, C. Tracing Nitrogen Sources and Cycling in Catchments. in C. Kendall, editor. Isotope Tracers in Catchment Hydrology. Amsterdam. Elsevier, 1998. p. 519-576

Kharkar, DP, Thomson J, Turekian HK and Forster WO. Uranium and Thorium in decay series nuclides in plankton from the Caribbean. Limnol Oceanogr 1976;21: 296-301.

Köster D, Pienitz, R, Wolfe BB., Barry S, Foster D , Dixit, SS. Paleolimnological assessment of human-induced impacts on Walden Pond (Massachusetts, USA) using diatoms and stable isotopes. Aquatic Ecosystem Health and Management 2005;8:117-31. 
Kraushal, S and Binford MW. Relationships between C:N ratios of lake sediments, organic matter sources and historical deforestation in Lake Pleasant, Massachusetts, USA. J. Paleolimnol. 1999;22:439-442.

Leavitt PR, Brock CS, Ebel C, Patoine A. Landscape-scale effects of urban nitrogen on a chain of freshwater lakes in central North America. Limnol Oceanog 2006: 51: $2262-$ 2277

Luthy, RG. Treatment of coal coking and coal gasification wastewaters.

Treatment of Coal Coking and Coal Gasification Water Poll. Control Fed. 1981;53:325-339

Majewska,RA, Zgrundo A, Lemke P, and DeStefano M. Benthic diatoms of the Vistula River estuary (Northern Poland): Seasonality, substrata preferences, and the influence of water chemistry. Phycol Res 2012;60:1-19

Mann, D.G Lyrella cassiteridum, a new species of marine epipelic diatom. Nord. J. Bot. 1997: 18:503-512.

Mann, DG and Stickle AJ Life history and systematics of Lyrella. Nova Hedwigia Beih 1993;106:43-70.

Melcer H, Nutt S, Marvan I, Sutton, P. Combined treatment of coke plant wastewater and blast furnace blow-down water in a coupled biological fluidized bed system. Journal Water Pollution Control Federation 1981;56:192-198

Mizutani H, Hasegawa H, Wada E High nitrogen isotope ratio for soils of seabird rookeries. Biogeochem 1986;2:221-247.

Moos, M, Laird KR, Cumming BF. Diatoms assemblages and water depth in Lake 239 (Experimental Lakes Area, Ontario); Implications of paleoclimatic studies. 2005. J.

Paleolimnol. 24:217-287.

Moura, AN, Bittencourt-Oliveira MC and Nascimento EC Benthic Bacillariophyta of the Paripe River estuary in Penambuco state, Brazil. Braz. J. Biol. 2007;67: 393-401

Round, F, Crawford RM, and Mann DG. Diatoms, Biology and Morphology of Genera. Cambridge, UK, Cambridge University Press, 1990.

Scheffer, M. and van Nes EH. Shallow lakes theory revisited: various alternative regimes driven by climate, nutrients, depth and lake size. Hydrobiol 2007;584:455-466.

Schindler D W, Hecky R E, Findlay D L, Stainton M P, Parker B R, Patterson M J, et al. Eutrophication of lakes cannot be controlled by reducing nitrogen input: Results of a 37year whole-ecosystem experiment. Proc Natl Acad Sci U S A 2008;105:11254-11258. 
Schindler DW, Wolfe AP, Vinebrooke R, Crow A, Blais JM, Miskimmin B. et al. The cultural eutrophication of Lac la Biche, Alberta, Canada: a paleoecological study. Can. J. Fish. Aquat. Sci. 2008;65:2211-2223.

Skele, M. The Great Knob. Illinois Historic Preservation Agency. Studies in Illinois Archaeology No. 41988.

Sparks, RE. Need for ecosystem management of large rivers and their floodplains. Bioscience 1995;45:168-182.

Sparks, RE, Nelson JC, and Yin Y. Naturalization of the flood regime in regulated rivers. Bioscience 199848:706-720.

Turner, RE, Rabelais NN, Fry B, Atilla N, Milan CS, Lee JN, et al. Paleo-indicators and water quality change in the Charlotte Harbor Estuary (Florida) Limnol. Oceanogr. 2006;51:518-533.

United States Environmental Protection Agency Horseshoe Lake, Madison County, Illinois. Working Paper Number 3121975.

Vermillion B, Brugam RB, Retzlaff WA, and Bala I The sedimentary record of environmental lead contamination at St Louis, Missouri (USA) area smelters J Paleolimnol 2005;33:189-203

Vreca P and Muri G. Changes in accumulation of organic matter and stable carbon and nitrogen isotopes in sediments of two Slovenian mountain lakes (Lake Ledvica and Lake Planina) induced by eutrophication changes Limnol. Oceanogr., 2006:51:781-790

Wolfe AP, Baron JS, Cornett RJ Anthropogenic nitrogen deposition induces rapid ecological changes in alpine lakes of the Colorado Front Range ( USA ). J of Paleolim. 2001;25:1-7

Zhang T, Ding L, Ren H, Xiong X Ammonium nitrogen removal from coking wastewater by chemical precipitation recycle technology. Water Res. 2009;43:5209-5215 


\section{Figure Captions}

1. Map of Horseshoe Lake showing surface samples and cores. Legend shows key to map colors

2. Isotopic values for sediment, phytoplankton and zooplankton taken in different basins of Horseshoe Lake. The dock samples were taken at the boat dock in the Main Basin of the lake. Numbers at the tops of columns indicate number of samples.

3. Age depth curves for cores H3, H5 and H8. Pollen dates from Vermillion et al. (2005).

4. Percent nitrogen, $\delta^{15} \mathrm{~N}$, percent carbon, $\delta^{13} \mathrm{C}$, and molar $\mathrm{C} / \mathrm{N}$ ratios in cores from Horseshoe Lake, Madison County, IL. Horizontal lines indicate historical events. The upper line shows the establishment of the coke plant in 1923. Bottom line indicates the establishment of Granite City (1895).

5. Reciprocal diagram for isotopic composition of samples from the Horseshoe Lake cores. The closed circles indicate samples that were deposited after 1920. Open circles indicate sediment deposited before 1920. Lines are regressions of $\delta^{15} \mathrm{~N}$ versus the reciprocal of the percent nitrogen in the core sample.

6. Diatom diagram from Horseshoe Lake core H8. Only the most abundant species are indicated. Exaggeration lines indicate 5X. Historic events (zone boundaries) indicate the start of coke plant operation (1923, 77 years before 2000) and the establishment of Granite City (1895, 105 years before 2000). 


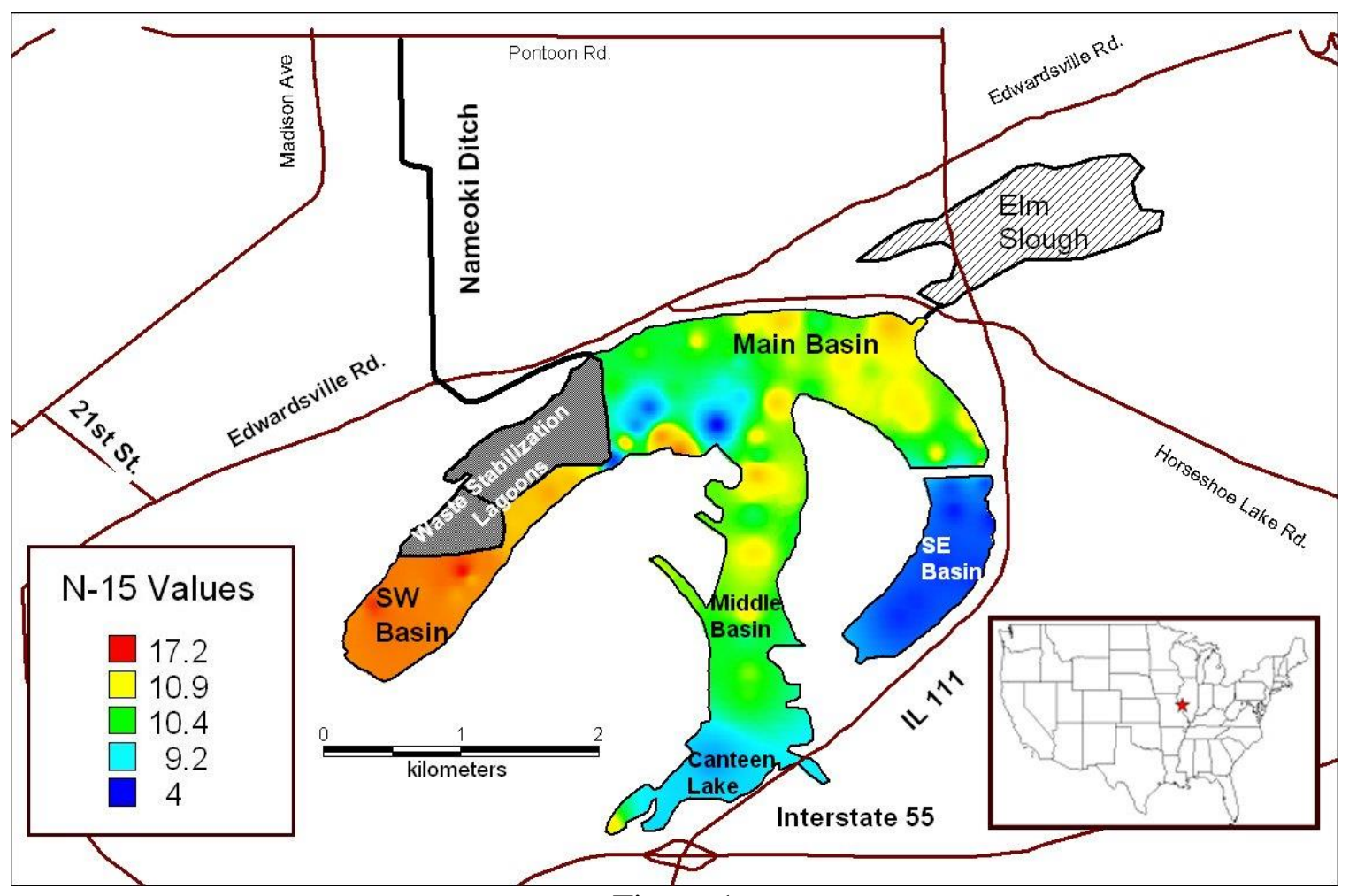

Figure 1 


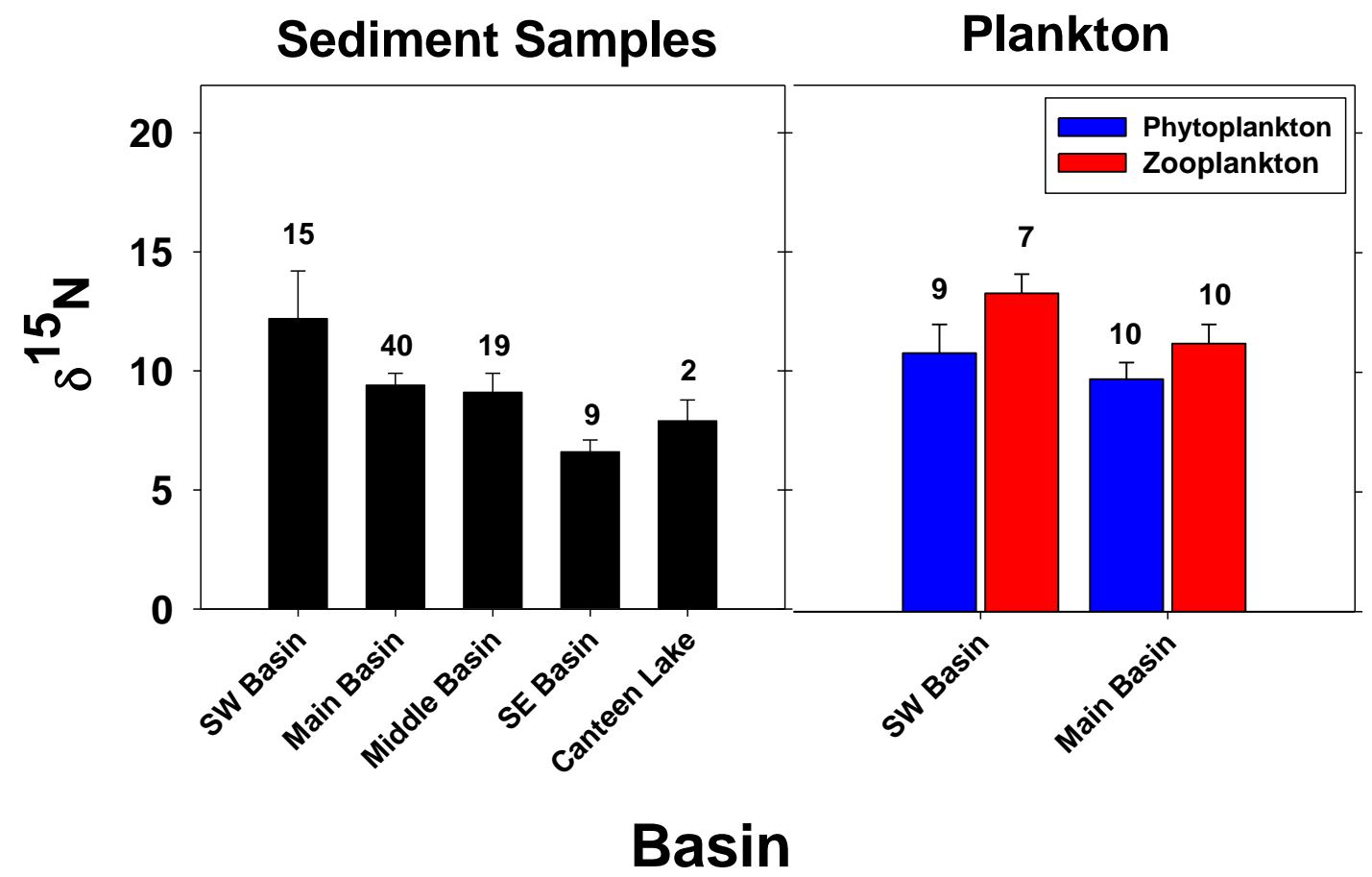

Figure 2 


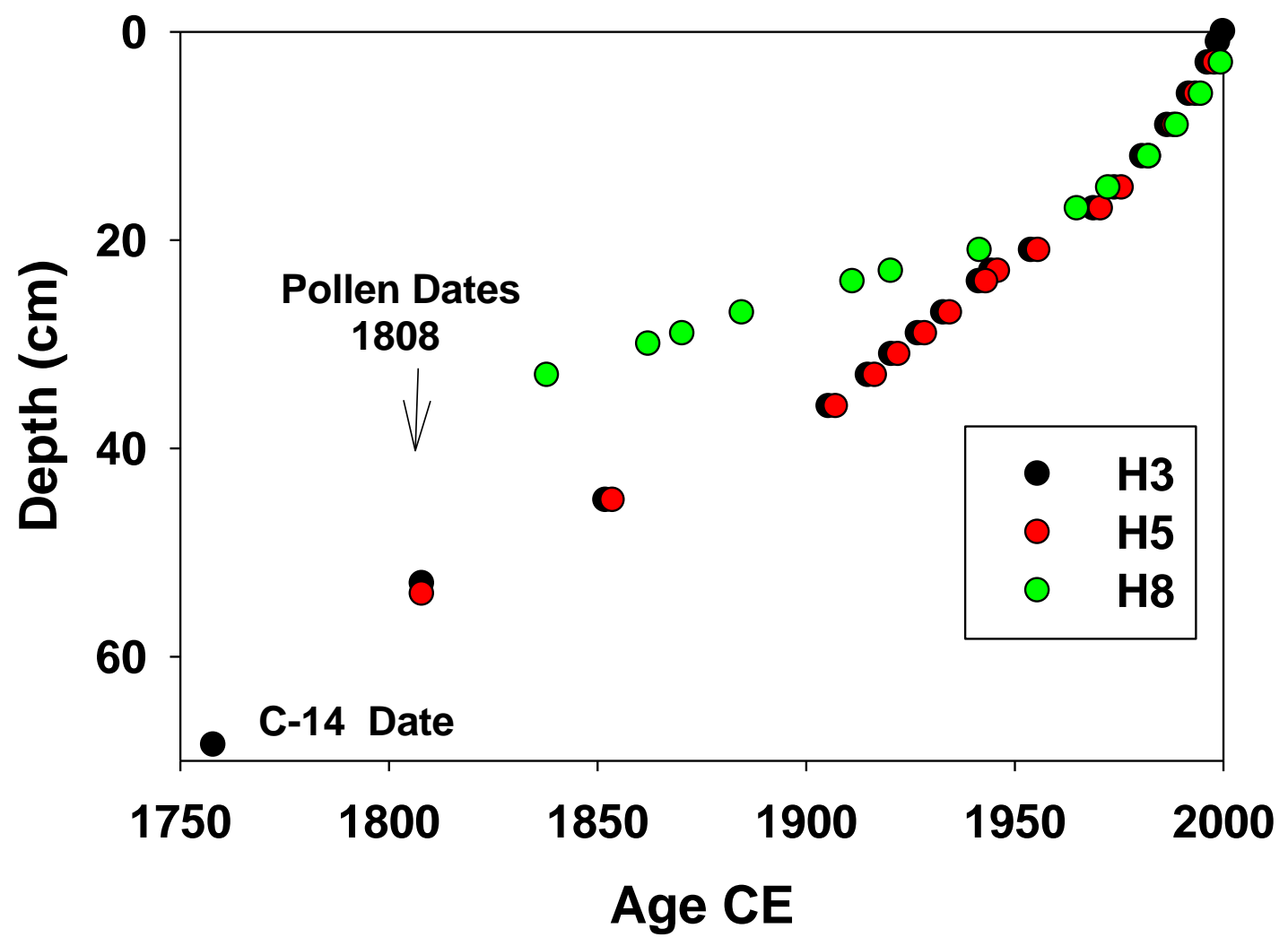

Figure 3 


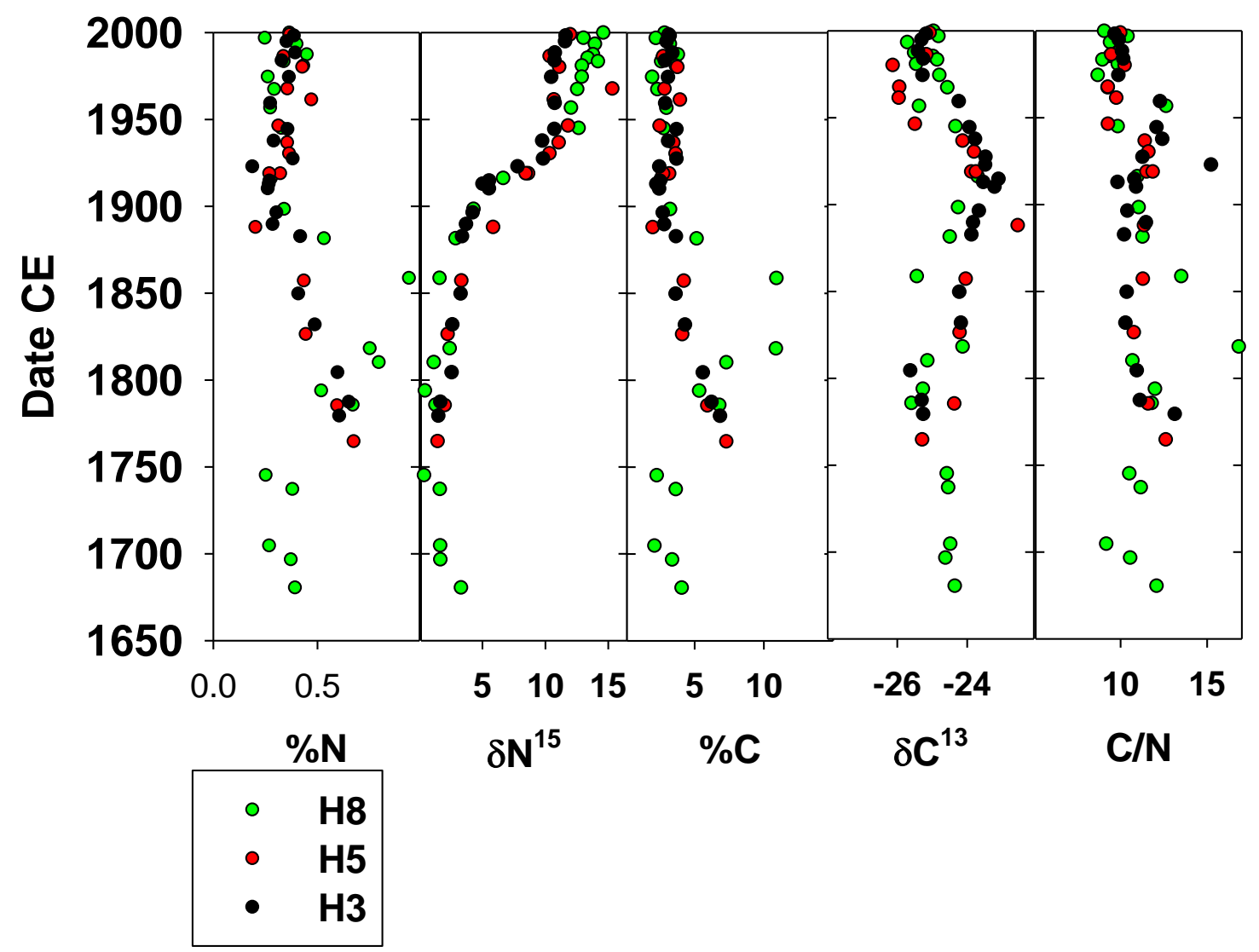

Figure 4 
- $\quad$ Core Samples After 1921

- Core Samples Before 1921

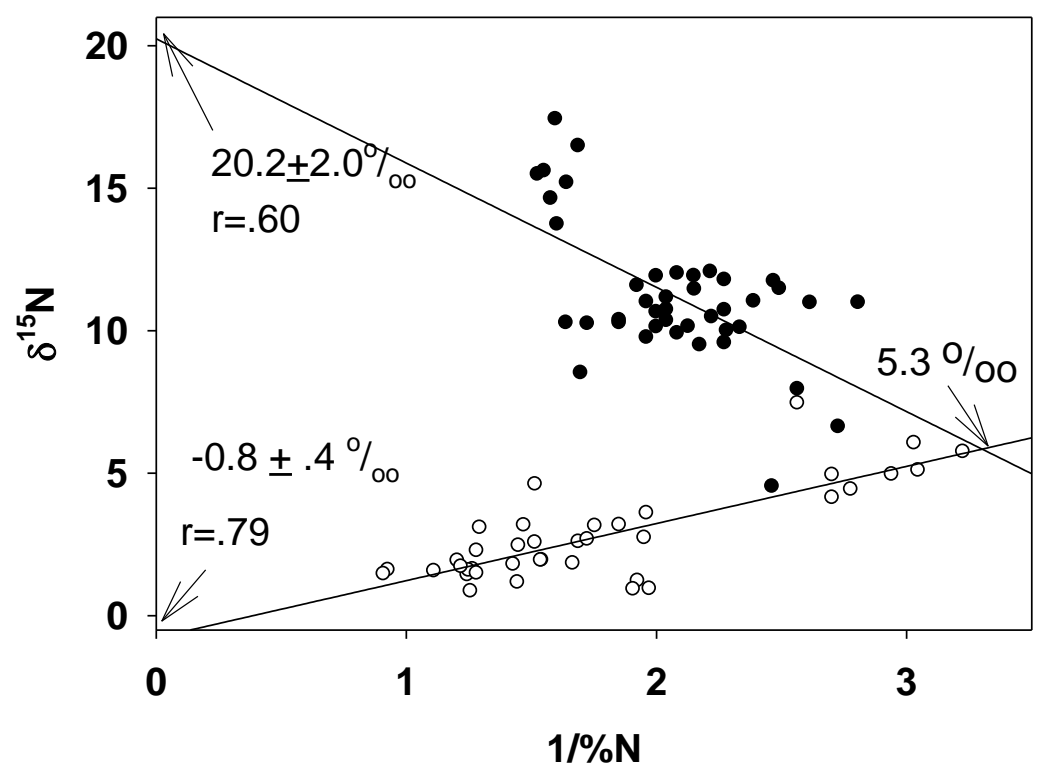

Figure 5 


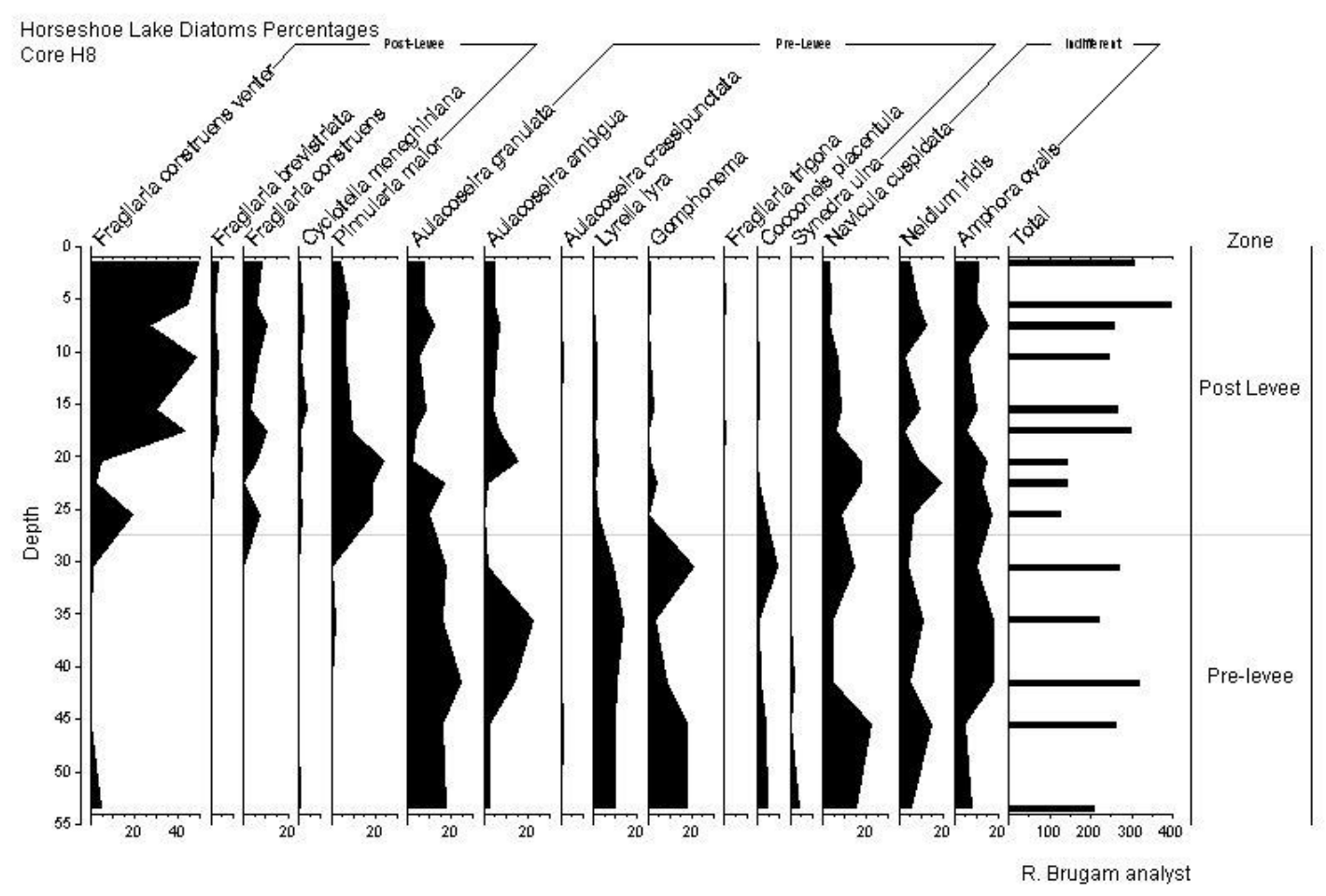

Figure 6 